\title{
Application of Optical Density in Evaluating Performance of Evolutionary Modified Perlite in Water Reclamation
}

\author{
Ali Reza Taheri Fard \\ Independent researcher; St. Petersburg, 195251, Russia; alireza_taherifard@yahoo.com
}

\begin{abstract}
:
Water treatment efficiency of several filter media such as perlite, modified (silicated) perlite, zeolite and sand were studied on wastewater. This study contains 2 distinct experiments which the first one emphasize on the modified perlite's performance in removing turbidity which has been gone through 3 phases including low turbidity model water, mid turbidity and high turbidity model water; the second experiment underlines the differentiation between 3 evolutionary material based on perlite which undergoes the filtration process with certain turbid model water. It was dedicated that modified perlite removed more than $90 \%$ of turbidity and it functions better than other materials with high turbidity (more than100 NTU). The experiments have been conducted with sodium silicate perlite, normal perlite and synthetic zeolite perlite in order to determine the optimized material which is able to be substituted with perlite in the filtration process.
\end{abstract}

Keywords: Water Treatment, Filtration, Modified Perlite, Optical density, wastewater

\section{Introduction:}

The current process for water treatment is reliant upon the quality of water sources. The surface water merely possesses more variant rather than groundwater in case of pollutants (1-3). Hence, the process might be complex for this type of water. Majority of surface water has turbidity more than the standards for the potable water. Although high-speed moving water may have larger suspended materials, most of the solids are colloid, therefore, chemical separation and filtration (sedimentation) are required to separate them. (4-6)Filtration or water treatment means remove solids from a liquid by passing it from a lattice or reticular chamber that these nets have very small openings (7). Filtration is the main part of many industries such as the major chemical industries (sulfuric acid production or caustic soda producers), water purification, food and beverage industry (8-9).

In the various branches of the filtration industry, the purpose is to obtain liquids with the highest purity in a shorter time and lower cost, which is not possible without proper filtering (10). Perlite is a type of rock that is a volcanic rock of volcanic glass which is heated sufficiently, expands from 4 to 30 times its initial size (11-13). From the middle of the third century BC, humans recognized this matter as a volcanic glass; the perlite originates from the word Perl means pearl (French word) (14). The perlite expands under heating due to the existence of 3-6\% water in the structure of perlite rocks. By heating perlite, the water in the structure and porosity of perlite rocks is evaporated and millions of very small bubbles are formed in the perlite structure (15-19). Thus, the structure of perlite is transformed into a porous structure with closed cells, the volume of its grains is strongly increased and its colour changes from black or dark grey to white. Perlite consists of silica oxide, aluminium, sodium, calcium, potassium, manganese, which is silica oxide possesses the highest percentage among other ingredients.(20-22) The expanded perlite is chemically neutral and after production, it becomes completely dry as well as white colour.

The structure of perlite is interconnected with tens of thousands of microscopic channels. This material provides an optimal flow rate. The same properties of perlite make it very effective in purifying food, drinking and medicine.(23)

Advantages of perlite as a filter media include reducing the cost with the help of perlite filter which implies perlite filter is 20 to $50 \%$ more than other filters, which is very significant in terms of cost reduction. The perlite filter density is only 110 to $270 \mathrm{~kg} / \mathrm{m} 3$. Experience shows that in using this filtering media in place of other filtering assistance in different industries leads to plunging the cost of refining without reducing efficiencies in the refinement (24-28).

Modified perlite which is discussed in this paper consists of perlite synthetic sodium silicate socalled SCP and zeolite synthetic perlite so-called ZP. The usage of these elements in water filtration is used for the first time by the author and there has been no background of using these materials in 
the filtration process. The environmental scientist in conducted a research on removing turbidity through perlite media in 2009in order to remove variants pollutants. Nonetheless, after stabilizing of filter media, turbidity removal efficiency was measured around 67\% (29). High transfer rate which is due to the perlite's unique physical structure, perlite filter contours help high-fluid transfer rates of high quality. It is particularly helpful for highly viscous liquids such as syrups or gelatinous fluids that require fast flow. (30)

This study obtains its theoretical experiment from the work Yzhang Wenv (31) carried out regarding measurement of turbidity by optical density device, furthermore, Jenni Ikonen (32) published an article on the usage of optical density measurement for finding turbidity of water. This study is reliant upon their investigation of using optical density for measuring turbidity, nonetheless, the novelty of paper is investigation of using optical density device in the application of evolutionary modified perlite which are newly introduced in scientific area of filtration material.

Simple cleaning of the mould which is the perlite filter, since this type of filter is porous and not compressed, it can be easily cleaned after the work is completed, which will help reduce manpower and increase productivity (33). Non-hazardous waste which perlite is not a dangerous waste and can be thrown away easily. Some moulds that are used in the food processor can be recycled even as part of livestock feed.

There has a gap in science which most of researcher and scientist ignored the application of perlite infiltration process due to having a high demand for membranes and ultra-membranes. This paper aims to fill the gap between the usage of perlite in decade ago and current researchers.

\section{Materials:}

\section{Model Water:}

In this study, model solution of natural water with various values of turbidity was used. It was made artificially by adding clay powder to tap water Saint petersburg, Russia. Clay powder was sieved through sieve number 200 (size of mesh $0.074 \mathrm{~mm}$ ). Tap water had concentration of total dissolved solids about $450 \mathrm{mg} / \mathrm{L}$.

Mixed Perlite Sodium Silicate (SCP):

Sodium silicate (liquid glass, food additive E550) are salts of silicon acids. For the first time, liquid glass in 1818 was received by the German chemist Jan Nepomuk von Fuchs. This compound is very widespread in nature. Silicates are contained in one third of all known mineral compounds (in clay materials, feldspar, mica). Sodium silicate is a white or whitish fine powder with no specific taste and odor. Liquid glass, dissolving in water, forms a viscous solution. In dilute solutions, sodium silicate decomposes into anions of silicic acid and sodium cations. When water is removed, the sodium silicate solution becomes an amorphous solid. Under the action of chlorides and acids, a silica gel (sorbent) is formed from the solution of the liquid glass. Viscous solutions of sodium silicate when heated to a temperature of $200-300^{\circ} \mathrm{C}$ are swollen and increase in volume by a factor of five to eight. At present, liquid glass is obtained by the method of autoclaving raw materials containing silica, concentrated solutions of sodium hydroxide. Methods are also known for the production of sodium silicate, based on the crystallization of melts from glasses, precipitation from the gas phase and solutions.

The sodium silicate was mixed with perlite with Ratio 1:0.75, after 3 minutes constant mixing sodium silicate with perlite, they were put into oven in 100 degree Celsius for 24 hours in order to dry sodium silicate and form a new material for filtration treatment. The physical properties of sodium silicate is represented in table 1:

\begin{tabular}{|c|c|}
\hline Weight $\mathrm{Na} 2 \mathrm{O} \%$ & 8.9 \\
\hline Weight $\mathrm{SiO} 2 \%$ & 28.7 \\
\hline Weight solids \% & 37.6 \\
\hline Density (g/cm3) & 1.38 \\
\hline
\end{tabular}

Table 1: shows physical properties of sodium silicate 
Synthetic Zeolite covered perlite (ZP):

Zeolites - a large group of similar in composition and properties of minerals, water aluminosilicates of calcium and sodium from a subclass of framework silicates, with a glass or pearlescent shine. Their main difference is that they absorb and emit not only water, but also other different molecules without changing the crystal structure. Absorption of molecules by zeolites is associated with the phenomenon of adsorption - the concentration of a substance from the gas phase on the surface of a solid (adsorbent) or in the volume formed by its pore structure.

The use of natural zeolites was limited due to their low adsorption capacity, they were used for gases and liquids with small molecule impurities, so they were used only to reduce water hardness. The situation changed when, in the 1950s, the first synthetic zeolites were obtained in R. Barrera's laboratory. Studies have shown that artificially synthesized zeolites as adsorbers have unique properties since they are capable of absorbing all components of complex mixtures. Also, they are able to purify substances even from a few undesirable impurities, which is very important for some types of industry.

\section{Methodology:}

Turbidity from Optical Density device:

Optical density (OD) is kin of light absorbance principle, which also called spectrophotometer. The density is generally measured through the scattering of light. Moreover, optical density is defined with respect to absorbance of light. On the other hand, spectrophotometer is an instrument to measure optical density or light absorbance, the principle of the measurement of optical density is by the absorbance of light energy.

The results have obtained from optic density device in order to receive OD number in 540 rays and also 364 so as to find turbidity of water and the color of water with the formula (34):

Turbidity (mg Caoline/L) $=\frac{((\text { OD 540-OD } 540 \text { (tap water })) * 5}{0.026}$

Color in degrees of Pt-Co scale $=$ OD $(364 \mathrm{~nm}, 1 \mathrm{~cm}) * 5 / 0.0065$

According to Russian standard for water quality (35), NTU of drinking water should not exceed 2.6, furthermore, Turbidity of drinking water in unit of $\mathrm{mg}$ Caoline/L should not exceed 1.5. Moreover, the color should not exceed $20^{\circ}$. The US EPA suggests lower than 2 NTU solely considering straight consumed reaping and unhindered irrigation, and Spain suggests lower than 10 NTU considering vegetables. The MOE lays the standards at level of under 2 NTU for food harvests, and lower 5 NTU for processed food crops (36).

Flow rate experiment:

The amount of flow (also known as volatility, fluid flow or spatial velocity) describes in physics and especially hydrodynamics as the amount of fluid passing through the single unit. Usually the symbol Q (sometimes V) is indicated as demonstration.

\section{Results:}

The first experiment has been conducted with two tubes containing sand and other tube contains perlite (passed through sieve no. 8) with (Synthetic Zeolite covered perlite) ZP as well as (mixed Perlite Sodium Silicate) SCP in order to measure the quality of having perlite and modified perlite materials filtered and measured to observe if there is a difference and major difference with removing turbidity of polluted water.

The tube was $100 \mathrm{~cm}$ height and $5 \mathrm{~cm}$ diameter, which was filled with $2.35 \mathrm{gr}$ perlite, $3.21 \mathrm{gr} \mathrm{ZP}$ and $3.45 \mathrm{gr}$ SCP; other tube was filled up with 12.8 gr sand.

The experiments include 3 diverge experiments including low turbid water, mid turbid water and high turbid water, which turbid water was created artificially by adding clays and some organic materials.

The results for three experiments are shown in Tables No. 2, 3, 4. 


\begin{tabular}{|l|l|l|l|l|l|l|}
\hline Materials & $\begin{array}{l}364 \text { (level } \\
\text { light } \\
\text { scattering) }\end{array}$ & $\begin{array}{l}540 \text { (level } \\
\text { light } \\
\text { scattering) }\end{array}$ & $\begin{array}{l}\text { Color } \\
\text { (Pt-Co scale) }\end{array}$ & $\begin{array}{l}\text { Turbidity } \\
\text { (mg Caoline/L) }\end{array}$ & $\begin{array}{l}\text { Turbidity } \\
\text { NTU }\end{array}$ & $\begin{array}{l}\text { Removing } \\
\text { Percentage }\end{array}$ \\
\hline Model Water & 0.1021 & 0.0553 & 78.53 & 10.63 & 18.33 & \\
\hline Sand & 0.0766 & 0.0363 & 58.92 & 6.98 & 12.035 & $34.34 \%$ \\
\hline $\begin{array}{l}\text { Modified } \\
\text { Perlite }\end{array}$ & 0.0780 & 0.0360 & 60 & 6.92 & 11.3 & $38.35 \%$ \\
\hline
\end{tabular}

Table 2: the result from Low turbidity

\begin{tabular}{|l|l|l|l|l|l|l|}
\hline Materials & $\begin{array}{l}364 \text { (level } \\
\text { light } \\
\text { scattering) }\end{array}$ & $\begin{array}{l}540 \text { (level } \\
\text { light } \\
\text { scattering) }\end{array}$ & $\begin{array}{l}\text { Color } \\
\text { (Pt-Co scale) }\end{array}$ & $\begin{array}{l}\text { Turbidity } \\
\text { (mgCaoline/L) }\end{array}$ & $\begin{array}{l}\text { Turbidity } \\
\text { NTU }\end{array}$ & $\begin{array}{l}\text { Removing } \\
\text { Percentage }\end{array}$ \\
\hline Model Water & 0.1416 & 0.1490 & 108.92307 & 28.65 & 49.39 & \\
\hline Sand & 0.0631 & 0.0365 & 48.5384 & 7.019 & 12.10 & $75.5 \%$ \\
\hline $\begin{array}{l}\text { Modified } \\
\text { Perlite }\end{array}$ & 0.0666 & 0.0311 & 51.2307 & 5.9807 & 10.311 & $79.12 \%$ \\
\hline
\end{tabular}

Table 3: the result from mid turbidity

\begin{tabular}{|l|l|l|l|l|l|l|}
\hline Materials & $\begin{array}{l}364 \text { (level } \\
\text { light } \\
\text { scattering) }\end{array}$ & $\begin{array}{l}540 \text { (level } \\
\text { light } \\
\text { scattering) }\end{array}$ & $\begin{array}{l}\text { Color } \\
\text { (Pt-Co scale) }\end{array}$ & $\begin{array}{l}\text { Turbidity } \\
\text { (mg Caoline/L) }\end{array}$ & $\begin{array}{l}\text { Turbidity } \\
\text { NTU }\end{array}$ & $\begin{array}{l}\text { Removing } \\
\text { Percentage }\end{array}$ \\
\hline Model Water & 9.2125 & 2.821 & 7086.5 & 542.5 & 935.34 & \\
\hline Sand & 2.19 & 0.431 & 1684.6 & 82.88 & 142.90 & $84.72 \%$ \\
\hline $\begin{array}{l}\text { Modified } \\
\text { Perlite }\end{array}$ & 1.771 & 0.256 & 1362.3 & 49.23 & 84.88 & $90.92 \%$ \\
\hline
\end{tabular}

Table 4: the result from high turbidity

The second phase of experiments have been conducted with materials through the tubes including perlite, modified perlite with zeolite and modified perlite with sodium silicate.

Afterwards, the water had been prepared artificially and went through all prepared tubes with $2.5 \mathrm{gr}$ perlite, 6.58 gr ZP and 4.735 gr SCP. Nevertheless, these set ups are reliant upon the height of tube which is $100 \mathrm{~cm}$, the tubes were filled with the materials in this height with minimum voids. Hence, pursuant to this set up, 2.5 gr perlite can fill the tube with determined height, 6.58 gr ZP and 4.735 gr SCP.

The experiments repeated two times in order to get precise results from optic density device, the results are shown in the table and the percentage of removing turbidity from water depicted in Fig 1: 


\begin{tabular}{|c|c|c|c|c|c|}
\hline materials & $\begin{array}{l}364 \text { (level light } \\
\text { scattering) }\end{array}$ & $\begin{array}{l}540 \text { (level light } \\
\text { scattering) }\end{array}$ & $\begin{array}{l}\text { Color } \\
\text { (Pt-Co scale) }\end{array}$ & $\begin{array}{l}\text { Turbidity } \\
\text { (mg Caoline/L) }\end{array}$ & $\begin{array}{l}\text { Turbidity } \\
\text { NTU }\end{array}$ \\
\hline Tap Water & 0.0784 & 0.0416 & & & \\
\hline $\begin{array}{l}\text { Model water } \\
\text { for P }\end{array}$ & 0.16085 & 0.10922 & 52.02282 & 13.005 & 22.42241 \\
\hline $\begin{array}{l}\text { Model water } \\
\text { for ZP }\end{array}$ & 0.17412 & 0.12332 & 62.86521 & 15.716 & 27.09655 \\
\hline $\begin{array}{l}\text { Model water } \\
\text { for SCP }\end{array}$ & 0.16105 & 0.11408 & 55.76131 & 13.940 & 24.03448 \\
\hline Perlite & 0.138 & 0.09021 & 18.697355 & 4.6743 & 8.05914 \\
\hline $\mathrm{ZP}$ & 0.1597 & 0.10304 & 23.63238 & 5.908 & 10.186205 \\
\hline SC perlite & 0.1253 & 0.08247 & 15.72191 & 3.93045 & 6.77664 \\
\hline
\end{tabular}

Table 5: the data of turbidity and color removal from water (first experiment)

\begin{tabular}{|c|c|c|c|c|c|}
\hline materials & $\begin{array}{l}364 \text { (level light } \\
\text { scattering) }\end{array}$ & $\begin{array}{l}540 \text { (level light } \\
\text { scattering) }\end{array}$ & $\begin{array}{l}\text { Color } \\
\text { (Pt-Co scale) }\end{array}$ & $\begin{array}{l}\text { Turbidity } \\
\text { (mg Caoline/L) }\end{array}$ & $\begin{array}{l}\text { Turbidity } \\
\text { NTU }\end{array}$ \\
\hline Tap Water & 0.0784 & 0.0416 & & & \\
\hline $\begin{array}{l}\text { Model water } \\
\text { for } \mathrm{P}\end{array}$ & 0.1475 & 0.1017 & 46.2593 & 11.5648 & 19.93931 \\
\hline $\begin{array}{l}\text { Model water } \\
\text { for } \mathrm{ZP}\end{array}$ & 0.1565 & 0.1084 & 51.41766 & 12.8544 & 22.16276 \\
\hline $\begin{array}{l}\text { Model water } \\
\text { for SCP }\end{array}$ & 0.1663 & 0.1130 & 54.9331 & 13.7332 & 23.67793 \\
\hline Perlite & 0.1322 & 0.07995 & 14.75075 & 3.68765 & 6.358015 \\
\hline $\mathrm{ZP}$ & 0.1626 & 0.09821 & 21.77406 & 5.4435 & 9.385345 \\
\hline SC perlite & 0.1309 & 0.07447 & 12.64559 & 3.16135 & 5.450605 \\
\hline
\end{tabular}

Table 6: the data of turbidity and color removal from water (second experiment) 


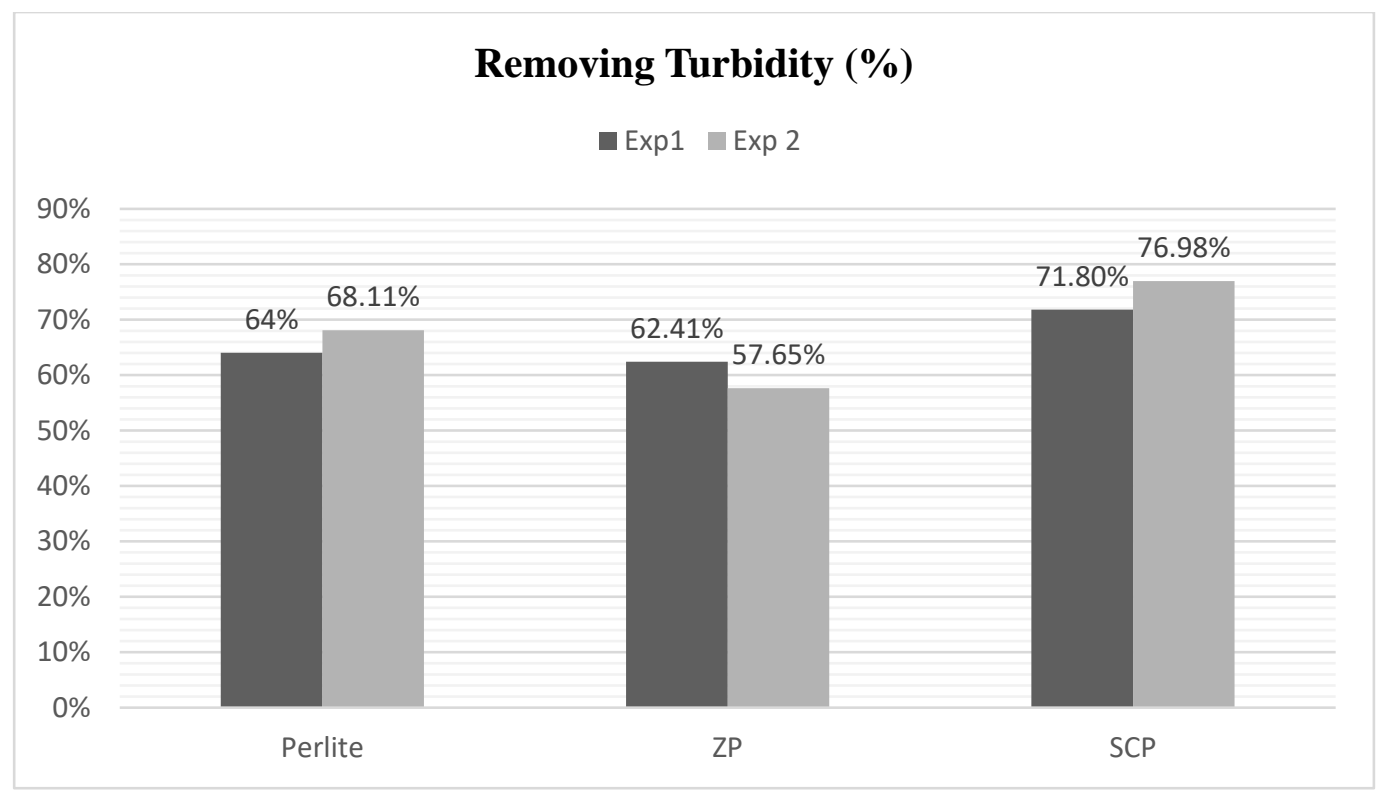

Fig 1: the percentage of removing turbidity from water

\section{Discussion:}

In the very first experiment, the combination of ZP and SCP and Perlite exceeds the sand in case of removing turbidity. Nonetheless, when it goes to higher turbidity as observation, the performance of modified perlite consists of ZP, SCP and perlite substantially are increased. In the high turbidity the combination of them achieved more than 90 percent of removing turbid of turbid water. It has demonstrated to us that the modified perlite can contribute removing turbidity, even though more experiments needed to be carried out which are mentioned in subsequent experiments.

It can be inferred from the second experiment that sodium silicate can remove turbidity itself and when it combines with the perlite which is highly porous the performance will show more effectiveness of it due to sodium silicate behaves as a coagulant per se, while working with the perlite it enhances the performance of water treatment. Zeolite itself is able to decrease the cations and anions in drinkable water as well as alleviation of adverse effect of water, thus synthetic zeolite was made and being merged with the expanded perlite.

\section{Conclusion:}

The conclusions obtained through the study are as follows:

1. Perlite also had shown better performance compared with sand in case of flow rate which perlite, SC perlite and synthetic zeolite ZP demonstrated flow rates respectively 5.15, 12.97 and 14.1 times more than sand in case of flow rate experiment.

2. With deliberation on first experiment, it can be inferred that the combination of ZP, SCP and perlite functions much better in high turbidity which reached more than 90 percent of removing turbidity of artificial turbid water as well as $79 \%$ in mid turbid water. In comparison, the performance of removing turbidity is merely $38 \%$ in rather low turbid water which decreases the performance of the modified perlite materials.

2. In comparison with the latest research which was done by Tae-Gyun, the removing turbidity in this research has been increased approximately $10 \%$, and attained the percentage of $76.98 \%$ in maximum removing efficiency.

3. In turbidity experiment, for the first time materials were gone under experiment and sodium silicate perlite has shown the best performance in case of removing turbidity up to $71.8 \%$. 


\section{Reference:}

1 Precoat filtration process from Bokela. (2015). Filtration + Separation, 52(3), p.8.

2 Ice, G. (2002). "A WATERSHED CONTROL AND MITIGATION HANDBOOK FOR FOREST PRACTICES: SOLUTIONS TO WATER QUALITY CONCERNS”. Proceedings of the Water Environment Federation, 2002(8), pp.207-222.

3 Ali Reza Taheri Fard (2017), "the Efficiency Evaluation of Applying Poly Ferric Sulfate and Perlite for Filtration”, Civil Eng Res J 2(5): CERJ.MS.ID.555599 (2017)

4 Yang, Y., Yang W.C., (2003) "Handbook of Fluidization and Fluid-Particle Systems", March 19, 2003 by CRC Press Reference - 878 Pages

5 APHA, AWWA, WEF, (2005) "Standard methods for the examination of water and wastewater", 21th ed., Washington D. C., pp. 3 13(2005).

6 Alkan, M., Demirbas, O. and Dog n, O., (2005) "Zeta potential of unexpanded and expanded perlite samples in various electrolyte media,"Micropor. Mesopor. Mat., 84(1-3), 192 200(2005).

7 Adams, F., Hategekimana, F. and Sylvester, O. (2017). Crude Oil Contaminated Water Treatment: Development of Water Filter from Locally Sourced Materials. Procedia Manufacturing, 7, pp.465-471.

8 Li, L., Teng, W., Zhang, J., Wu, W. and Shang, Q. (2017). Effect of Surface Vitrification on the Properties of Insulation Board of Expanded Perlite. Key Engineering Materials, 726, pp.586-590.

9 Rodriguez, J., Soria, F., Geronazzo, H. and Destefanis, H. (2016). Modification and characterization of natural aluminosilicates, expanded perlite, and its application to immobilise $\alpha$-amylase from A. oryzae. Journal of Molecular Catalysis B: Enzymatic, 133, pp.S259-S270.

10 Tsikouras, B., Passa, K., Iliopoulos, I. and Katagas, C. (2016). Microstructural Control on Perlite Expansibility and Geochemical Balance with a Novel Application of Isocon Analysis: An Example from Milos Island Perlite

11 Hsieh, C. and Davis, A. P., (2005) "Evaluation and optimization of bioretention media for treatment of urban storm water runoff,"J. Envion. Eng-ASCE., 131(11), 1521 1531(2005).

12 Qi, P., Lin, N., Liu, Y. and Zhao, J. (2013). Improvement of oil/water selectivity by stearic acid modified expanded perlite for oil spill cleanup. Journal of Shanghai Jiaotong University (Science), 18(4), pp.500507.

13 Majouli, A., Younssi, S., Tahiri, S., Albizane, A., Loukili, H. and Belhaj, M. (2011). Characterization of flat membrane support elaborated from local Moroccan Perlite. Desalination, 277(1-3), pp.61-66.

14 S.R. Movafagh, A.R. Taheri Fard, H. Malah, M.Yu. Andrianova,(2017) Approbation of alternative polymeric coagulants to eliminate turbidity of model surface waterm, Construction of Unique Buildings and Structures, 2017, №2 (53).

15 Kucharczyk, W., Dusiński, D., Żurowski, W. and Gumiński, R. (2017). Effect of composition on ablative properties of epoxy composites modified with expanded perlite. Composite Structures, 183, pp.654-662.

16 Irani, M., Amjadi, M. and Mousavian, M. (2011). Comparative study of lead sorption onto natural perlite, dolomite and diatomite. Chemical Engineering Journal, 178, pp.317-323.

17 Yoon, C.G.; Han, J.Y.; Jung, K.W.; Jang, J.H. (2006) Quantitative microbial risk assessment of wastewater reuse for irrigation in paddy field. J. Korean Soc. Agric. Eng. 2006, 48, 77-87.

18 Jeong, H.S.; Park, J.H.; Seong, C.H.; Jang, T.I.; Kang, M.S.; Park, S.W.(2013) Effects of indirect wastewater reuse on water quality and soil environment in paddy fields. J. Korean Soc. Agric. Eng. 2013, 55, 91-104.

19 Huertas, E.; Salgot, M.; Hollender, J.; Weber, S.; Dott, W.; Khan, S.; Schafer, A.; Messalem, R.; Bis, B.; Aharoni, A.; Chikurel, H. (2008) Key objectives for water reuse concepts. Desalination 2008, 218, 120 131.

20 Evans, A.E.V.; Hanjra, M.A.; Jiang, Y.; Qadir, M.; Drechsel, P.(2012) Water pollution in Asia: The urgent need for prevention and monitoring. Water Qual. 2012, 9, 1-4

21 Andrianova, M., Molodkina, L. and Chusov, A. (2014). Changing of Contaminants Content and Disperse State during Treatment and Transportation of Drinking Water. Applied Mechanics and Materials, 587 589, pp.573-577.

22 Bastani, D., Safekordi, A., Alihosseini, A. and Taghikhani, V. (2006). Study of oil sorption by expanded perlite at 298.15K. Separation and Purification Technology, 52(2), pp.295-300.

23 Gironás, J., Adriasola, J. and Fernández, B. (2008). Experimental Analysis and Modeling of a Stormwater Perlite Filter. Water Environment Research, 80(6), pp.524-539.

$24 \mathrm{Kang}$, Joo H. et al. Particle destabilization in highway runoff to optimize pollutant removal. Journal of Environmental Engineering. (2007). 133 (4): 426-434.

25. Brissaud, F. (2008) Criteria for water recycling and reuse in the Mediterranean countries. Desalination 2008, 218, 24-33. 
26 Ju, X.T.; Kou, C.L.; Zhang, F.S.; Christie, P. (2006) "Nitrogen balance and groundwater nitrate contamination" Comparison among three intensive cropping systems on the North China Plain. Environ. Pollut. 2006, 143, 117-125.

27. Inbar, Y. (2007) "New standards for treated wastewater reuse in Israel. In Wastewater Reuse-Risk Assessment”, Decision-Making and Environmental Security; Zaidi, M., Ed.; Springer: Dordrecht, The Netherlands, 2007; pp. 291-296.

28 Jang, T.; Lee, S.B.; Sung, C.H.; Lee, H.P.; Park, S.W.(2010) Safe application of reclaimed water reuse for agriculture in Kora. Paddy Water Environ. 2010, 8, 227-233.

29 Tae-Gyun Kim Kang-Woo Cho Kyung-Guen SongMin-Hyuk Yoon Kyu-Hong Ahn , Sung-Kwan Hong (2009), Evaluation of the Removal Characteristics of Pollutants in Storm Runoff Depending on the Media Properties, Journal of Korean Society of Environmental Engineers, Volume 31, Issue 7, 2009, pp.483-490

30 Kretschmer, N.; Ribbe, L.; Gaese, H. (2002) "Wastewater Reuse for Agriculture". Technol. Resour. Manag. Dev. Sci. Contrib. Sustain.. 2002, 2, 37-64.

31 Yizhang Wen et al 2016 J. Phys.: Conf. Ser. 679012028

32 Jenni Ikonen (2013), Suitability of Optical, Physical and Chemical Measurements for Detection of Changes in Bacterial Drinking Water Quality, Int J Environ Res Public Health. 2013 Nov; 10(11): 53495363

33 Bristow, C.M., Scott, P.W., (2002) “Industrial Minerals and Extractive Industry Geology”, Geological Society Pub House, 2002.

34 Balch R. T. (1931), "Mesurement of turbidity with a spectrophotometer, Industrial and Engineering Chemistry Analytical, Volume3, Issue2

35 Water code of the Russian federation, Russian Federation Federal Law, April 2006

36 Hanseok Jeong 1 , Hakkwan Kim 1,* and Taeil Jang 2 (2016), "Irrigation Water Quality Standards for Indirect Wastewater Reuse in Agriculture" A Contribution toward Sustainable Wastewater Reuse in South Korea, Water 2016, 8, 169 